\title{
ANALISIS ALASAN MEMILIH BERSALIN DI RUMAH DI WILAYAH KERJA PUSKESMAS SITOPENG KOTA CIREBON TAHUN 2016
}

\author{
Nurasih $^{1}$ Endang Nurrochmi ${ }^{2}$ \\ ${ }^{1,2)}$ Poltekkes Kemenkes Tasikmalaya Program Studi Kebidanan Cirebon \\ e-mail : nurasih1610@yahoo.co.id
}

\begin{abstract}
In the city of Cirebon, there are births at the client's home attended by bealth personnel, while the government policy requires childbirth should be performed in health facilities. It was also apparent in the achievement gaps concerning childbirth in health facility that $4.5 \%$ of deliveries were not performed in health facilities. This was a descriptive research using a qualitative approach through in-depth interviews. The sample in this study consisted of 14 parturients and 2 midwives. The results showed that the respondents aged between 19-45 years, had a parity of 1-10, had a background of elementary education, were bousewives, and delivered a baby with a normal birth process. The reasons that the informants chose to have a home birth were because of the comfort and family customs and feeling uncomfortable and impractical to give birth in health facilities; however, distance was not a problem in deliveries in health facilities. According to the midwives, home birth was felt less secure, although the time to help the childbirth was short. Many obstacles were encountered in connection with preparation or place and emergency events could somehow not be predicted in advance. The main reason to have a home birth was according to the midwives due to comfort perceived by the parturients. This study found that the parturients loved to have a bome birth for reasons of practicality and comfort. There was still a cultural influence on the decision why they chose a home birth. Therefore, midwives are expected to empower pregnant women
\end{abstract}

Keywords: Analysis of the reasons, home birth.

\begin{abstract}
ABSTRAK
Di Kota Cirebon masih terdapat persalinan yang ditolong oleh tenaga kesehatan yang dilakukan di rumah klien, sedangkan kebijakan pemerintah mengharuskan persalinan di fasilitas kesehatan. Penelitian ini merupakan penelitian deskriptif dengan pendekatan kualitatif melalui wawancara mendalam. Sampel dalam penelitian ini terdiri dari 14 orang ibu bersalin dan 2 orang Bidan. Hasil penelitian didapatkan bahwa usia responden antara 19 - 45 tahun, paritas $1-10$, pendidikan SD, pekerjaan sebagai IRT, dan dengan persalinan normal. Alasan informan bersalin di rumah karena kenyamanan dan kebiasaan keluarga yang sudah berlangsung, merasa kurang nyaman dan tidak praktis melahirkan di fasilitas kesehatan, jarak tidak menjadi masalah dalam persalinan di fasilitas kesehatan. Persalinan di rumah menurut informan Bidan dirasakan kurang aman, meskipun waktu menolong persalinannya menjadi singkat, banyak hambatan yang ditemui terkait dengan persiapan penolong maupun tempat dan kejadian kegawatdaruratan yang tidak dapat diprediksi sebelumnya. Alasan bersalin dirumah yang diketahui oleh Bidan lebih kepada kenyamanan yang dirasakan oleh ibu bersalin. Kesimpulan dalam penelitian ini didapatkan bahwa ibu bersalin menyukai persalinan di rumah dengan alasan kepraktisan dan kenyamanan. Masih
\end{abstract}


terdapat pengaruh budaya terhadap keputusan ibu memilih persalinan di rumah. Bidan diharapkan dapat melakukan pemberdayaan pada ibu hamil.

Kata Kunci : Analisis alasan, Persalinan di rumah

\section{PENDAHULUAN}

Sebagaimana diketahui dari beberapa pencapaian tujuan pembangunan kesehatan nasional serta MDGs, kita menghadapi berbagai hal yang multi kompleks seperti masalah budaya, pendidikan masyarakat, pengetahuan, lingkungan, kecukupan fasilitas kesehatan, sumberdaya manusia dan lainnya. Penurunan Angka Kematian Ibu (AKI) dan Angka Kematian Bayi (AKB) merupakan tantangan yang lebih sulit dicapai dibandingkan target MDGs lainnya. Oleh karena itu, upaya penurunan AKI tidak dapat lagi dilakukan dengan intervensi biasa, diperlukan upaya-upaya terobosan serta peningkatan kerjasama lintas sektor untuk mengejar ketertinggalan penurunan AKI agar dapat mencapai target MDGs. Salah satu faktor yang penting adalah perlunya meningkatkan akses masyarakat terhadap persalinan yang sehat dengan cara memberikan kemudahan pembiayaan kepada seluruh ibu hamil yang belum memiliki jaminan persalinan untuk meningkatkan persalinan yang ditolong tenaga kesehatan, di fasilitas kesehatan dalam upaya menjamin akses pelayanan persalinan maka pada tahun 2011 Kementerian Kesehatan meluncurkan upaya terobosan berupa Jaminan Persalinan (Jampersal). Dengan demikian kehadiran jampersal di harapkan dapat mengurangi terjadinya Tiga Terlambat tersebut sehingga dapat mengakselerasi tujuan pencapaian MDGS, khususnya MDGS 4 dan 5 (Prasetyawati, 2012)

Tempat bersalin termasuk salah satu faktor yang dapat mempengaruhi psikologis ibu bersalin. Pemilihan tempat bersalin dan penolong persalinan yang tidak tepat akan berdampak secara langsung pada kesehatan ibu. Setidaknya ada dua pilihan tempat bersalin yaitu di rumah ibu atau di unit pelayanan kesehatan. Di Indonesia diketahui bahwa $80 \%$ masyarakatnya tinggal di pedesaan, dan $100 \%$ wanita menyukai suasana rumah/tinggal di rumah.Di Negara berkembang dimana perempuan mungkin tidak mampu membayar biaya perawatan medis atau tidak dapat mengaksesnya, melahirkan di rumah mungkin satusatunya pilihan yang tersedia, dan bahkan wanita itu mungkin atau tidak dapat dibantu oleh tenaga profesional, dan 
mungkin yang ada hanya dukun atau menolong sendiri tanpa bantuan siapapun. Saat ini di luar negeri dan di perkotaan yang pada kenyataannya akses ibu terhadap pelayanan kesehatan mudah dan terjangkau justru menginginkan untuk mendapatkan pelayanan persalinan di rumah (bome birth). Keamanan melahirkan di rumah telah menjadi subjek kontroversi, terutama antar kelompok dokter professional. Namun sejumlah penelitian telah menunjukkan bahwa keselamatan melahirkan di rumah bagi perempuan berisiko rendah adalah sama dengan risiko melahirkan di rumah sakit atau klinik bersalin.

Laporan Riskesdas 2010 tentang persentase tempat ibu melahirkan menurut tempat persalinan berdasarkan karakteristik tempat tinggal dan status ekonomi didapatkan bahwa di pedesaan umumnya persalinan dilakukan di rumah/lainnya, sedangkan di perkotaan melahirkan di fasilitas kesehatan lebih banyak. Makin tinggi status ekonomi seseorang akan lebih memilih tempat persalinan di fasilitas kesehatan, sebaliknya semakin rendah status ekonomi makan memilih untuk persalinan di rumah sehingga persentase persalinan di rumah makin besar. (Laporan Riskesdas, 2010). Dalam sebuah artikel yang diterbitkan dalam Acta Obstetricia et Gynecologica Scandinovica (2010), ada beberapa faktor yang menyebabkan ibu memilih bersalin di rumah, diantaranya lingkungan rumah yang nyaman, tidak suka dengan rumah sakit atau rumah bersalin, dapat mengurangi stres, dan mempunyai kontrol atau otonomi yang lebih besar terhadap diri sendiri.Rumah merupakan lingkungan yang sudah dikenal wanita sehingga ia dapat merasa nyaman dan relaks selama persalinan, tempat ia dapat mempertahankan privasi dan dikelilingi oleh orang-orang yang diinginkannya, yang memberikan dukungan dan ketenangan pada dirinya. Kehadiran pendamping selama proses persalinan, sentuhan, hiburan dan dorongan untuk mendukung, sangat besar artinya karena dapat membantu ibu saat proses persalinan.

Cakupan persalinan oleh tenaga kesehatan di Kota Cirebon pada tahun 2013 sebesar 86,32\%. Cakupan tersebut menurun jika dibandingkan pada tahun 2012 yakni sebesar 88,47\%, dengan kisaran tertinggi berada di Kelurahan Argasunya Puskesmas Sitopeng sebesar $115,89 \%$. Jika dibandingkan dengan target Kota Cirebon tahun 2013 (88\%) dan Target Kemenkes 2015 (95\%) belum 
memenuhi target yang diharapkan. Menurut data Dinas Kesehatan Kota Cirebon pada tahun 2010 dari jumlah persalinan 5459, yang di tolong oleh tenaga kesehatan di fasilitas kesehatan sebanyak 4616, dan yang di tolong di non fasilitas kesehatan (rumah) sebanyak 769 orang. Data Puskesmas Sitopeng Kota Cirebon pada tahun 2010 dari jumlah total ibu bersalin sebesar 355 orang dan yang memilih bersalin di rumah sebanyak 230, sedangkan di fasilitas kesehatan 125 orang. Sementara itu pada tahun 2013 di Kota Cirebon cakupan persalinan di fasilitas kesehatan sebesar 81,81\%, ada kesenjangan 4,5\% dengan yang tidak bersalin di fasilitas kesehatan. Ini artinya masih ada pertolongan persalinan yang diberikan oleh tenaga kesehatan di rumah klien yaitu yang berada di wilayah Kelurahan Argasunya Puskesmas Sitopeng.Sesuai dengan data kesenjangan cakupan persalinan Nakes di Argasunya sebesar 65,15\% (dari cakupan persalinan nakes $115,89 \%$ hanya $50,70 \%$ yang bersalin di fasilitas kesehatan) (Dinkes Kota Cirebon, 2013). Berdasarkan hasil rekapitulasi laporan persalinan Puskesmas Sitopeng pada tahun 2015, terdapat jumlah ibu bersalin di rumah sebesar 238 orang dari 506 persalinan, sehingga dapat disimpulkan bahwa masih banyak ibu bersalin di non fasilitas kesehatan di Puskesmas Sitopeng Kota Cirebon.

\section{METODE PENELITIAN}

Penelitian ini merupakan penelitian deskriptif dengan pendekatan kualitatif melalui wawancara mendalam (indept interview) (Notoatmodjo S, 2005). Penelitian ini dilakukan di wilayah kerja Puskesmas Sitopeng dengan pertimbangan bahwa Puskesmas Sitopeng masih banyak ibu bersalin yang memilih bersalin di rumah. Informan dalam penelitian ini adalah ibu yang telah melahirkan di rumah di wilayah kerja Puskesmas Sitopeng Kota Cirebon tahun 2016, baik yang melahirkan ditolong oleh dukun maupun oleh tenaga kesehatan dan bersedia menjadi informan (informan 1), Bidan Puskesmas (informan 2). Pengambilan sampel dalam penelitian ini secara snowball sampling dan didapatkan sebanyak 14 orang informan (ibu melahirkan) dan 2 orang informan (Bidan). Pengumpulan data dengan tehnik wawancara mendalam menggunakan panduan yang disusun oleh peneliti sendiri. Selanjutnya agar hasil wawancara terdokumentasikan dengan baik maka diperlukan alat-alat sebagai berikut : buku catatan, tape recorder dan camera. Analisis data kualitatif dilakukan bersamaan dengan proses pengumpulan 
data, memuat 3 kegiatan besar yaitu, reduksi data, penyajian data, dan penarikan kesimpulan. Pada proses reduksi peneliti harus benar-benar mencari data yang valid (Basrowi dan Suwandi, 2008). Analisis data dalam penelitian kualitatif, dilakukan pada saat pengumpulan data berlangsung, dan setelah selesai pengumpulan data dalam periode tertentu. Pada saat wawancara, peneliti sudah melakukan analisis terhadap jawaban yang diwawancarai. Bila jawaban hasil wawancara setelah dilakukan analisis terasa belum memuaskan, maka peneliti akan melanjutkan pertanyaan lagi, sampai tahap tertentu, diperoleh data yang dianggap kredibel. (Sugiono, 2012).

\section{Alasan memilih Bersalin di rumah}

Hasil penelitian didapatkan bahwa sebagian besar informan mengemukakan memilih persalinan di rumah karena bayinya mau keluar atau terlanjur keluar (kebrojolan). Seperti tampak pada pernyataan salah satu informan berikut ini :

"tidak sempat dibawa ke rumah bu Bidan karena sudah keburu labir, sayanya kebrojolan padahal saya telpon bu Bidannya".

\section{Keuntungan Bersalin di Rumah}

Hasil penelitian didapatkan bahwa banyak keuntungan yang dirasakan oleh informan saat melahirkan di rumah diantaranya merasa nyaman berada di lingkungan keluarga, karena ada dukungan dari keluarga, ada yang menemani, merasa tenang karena dapat mengawasi anak yang lain, bisa beraktifitas, tidak merasa repot karena harus mengangkut barang bawaan untuk persiapan persalinan. Seperti tampak pada pernyataan beberapa informan berikut ini :

"enaknya di rumah segalanya ada".

"ada keluarga yang nemenin".

\section{Kerugian yang dirasakan Informan saat Bersalin di Fasilitas Kesehatan}

Hasil penelitian didapatkan bahwa beberapa informan menyatakan merasa kerepotan berkaitan dengan barangbarang yang harus dibawa jika melahirkan di rumah Bidan, apalagi jika ada beberapa barang yang tertinggal di rumah.

\section{Perasaan pada saat Bersalin ditolong oleh tenaga Kesehatan/Paraji}

Berdasarkan hasil penelitian didapatkan bahwa informan menyatakan lebih enak melahirkan di Bidan karena sifatnya yang ramah, sabar, dikunjungi ke rumah setelah melahirkan, dan tidak mengeluarkan biaya persalinan. 


\section{HASIL}

Pada Tabel 1 di bawah, didapatkan bahwa usia responden antara 19 - 45 tahun, paritas 1 10, tingkat pendidikan SD, pekerjaan sebagai IRT, dan dengan persalinan normal.

\section{Tabel 1. Identitas Informan (Ibu Melahirkan)}

\begin{tabular}{ccccccc}
\hline $\begin{array}{c}\text { Kode } \\
\text { Informan }\end{array}$ & $\begin{array}{c}\text { Inisial } \\
\text { Nama }\end{array}$ & Umur & Paritas & Pendidikan & Pekerjaan & \multicolumn{1}{c}{ Diagnosa } \\
\hline R1 & Ny. MI & 42 & 10 & SD & IRT & $\begin{array}{l}\text { Partus Normal } \\
+\end{array}$ \\
& & & & & & $\begin{array}{l}\text { Grandemultip } \\
\text { ara }\end{array}$ \\
\hline R2 & Ny. PI & 35 & 3 & SD & IRT & Partus Normal \\
\hline R3 & Ny. AH & 36 & 5 & SD & IRT & Partus Normal \\
\hline 4 & Ny. KH & 28 & 2 & SD & IRT & Partus Normal \\
\hline R5 & Ny. & 20 & 2 & SD & IRT & Partus Normal \\
\hline R6 & Ny. SM & 35 & 6 & SD & IRT & $\begin{array}{l}\text { Partus Normal } \\
+\end{array}$ \\
& & & & & & $\begin{array}{l}\text { Grandemultip } \\
\text { ara }\end{array}$ \\
\hline R7 & Ny. TN & 42 & 5 & SD & IRT & PEB \\
\hline R8 & Ny. SU & 30 & 3 & SD & IRT & Partus Normal \\
\hline R9 & Ny. SA & 19 & 2 & SD & IRT & Partus Normal \\
\hline R10 & Ny. LM & 19 & 1 & SD & IRT & Partus Normal \\
\hline R11 & Ny. JH & 26 & 2 & SD & IRT & Partus Normal \\
\hline R12 & Ny. AH & 20 & 1 & SD & IRT & Partus Normal \\
\hline R13 & Ny. MS & 23 & 2 & SD & IRT & Partus Normal \\
\hline R14 & Ny. AT & 45 & 4 & SD & IRT & Partus Normal \\
\hline & & & & & & \\
\hline & & & & & & \\
\hline
\end{tabular}

Tabel 2. Identitas Informan (Bidan)

\begin{tabular}{ccccc}
\hline $\begin{array}{c}\text { Kode } \\
\text { Informan }\end{array}$ & $\begin{array}{c}\text { Inisial } \\
\text { Nama }\end{array}$ & Umur & Pendidikan & Alamat \\
\hline R15 & TK & 42 th & D.IV KeBidanan & PKM Sitopeng \\
\hline R16 & HN & 45 th & D.IV KeBidanan & PKM Sitopeng
\end{tabular}

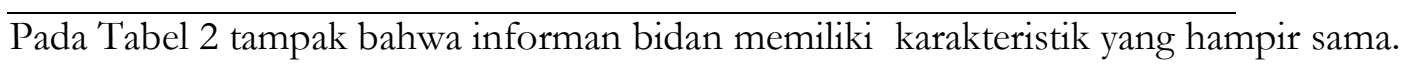




\section{Jarak ke Fasilitas Kesehatan}

Hasil penelitian mengungkapkan bahwa sebagian informan tidak mempermasalahkan jarak dari rumah ke fasilitas kesehatan, karena sudah tersedia fasilitas transportasi yang sudah disiapkan oleh Puskesmas.

\section{Persepsi Bidan tentang Persalinan di}

\section{Rumah}

Hasil penelitian didapatkan bahwa persalinan di rumah dapat dilakukan asal dengan persiapan yang matang.

\section{Keuntungan yang dirasakaan pada} saat Menolong Persalinan di Rumah

Hasil penelitian mengungkapkan bahwa keuntungan yang dirasakan informan pada saat menolong persalinan di rumah lebih kepada waktu yang lebih singkat pada saat menunggu persalinan.

\section{Hambatan saat Menolong Persalinan di Rumah}

Hasil penelitian didapatkan bahwa hambatan yang dirasakan Bidan pada saat menolong persalinan di rumah adalah pada saat menemui kasus kegawatdaruratan.

\begin{abstract}
Alasan Masyarakat tetap Memilih Persalinan di Rumah

Hasil penelitian mengungkapkan bahwa sebagian besar ibu memilih bersalin di rumah karena merasa nyaman berada di lingkungan keluarganya, ada dukungan penuh dari keluarga, tidak asing dengan lingkungan tempat bersalin.
\end{abstract}

\section{PEMBAHASAN}

\section{Identitas Informan}

Penelitian ini dilakukan di Puskesmas Sitopeng Kota Cirebon pada ibu melahirkan periode Agustus s.d Oktober 2016. Didapatkan Informan Ibu melahirkan (14 orang), Bidan (2 orang). Masih terdapat informan Ibu melahirkan dengan persalinan grande multipara dan usia diatas 35 tahun, dimana ibu risiko terhadap kegawatdaruratan dalam persalinan, diantaranya seperti perdarahan, sejalan dengan teori yang mengemukakan bahwa usia yang aman untuk kehamilan dan persalinan adalah usia 20 - 35 tahun (Notoatmodjo, 2005).

\section{Alasan Memilih Bersalin di rumah \\ Persalinan di rumah merupakan persalinan yang dilakukan di rumah, bukan di rumah sakit, bukan di rumah bersalin, ataupun di tempat praktik Bidan}


(Aprillia, 2013). Persalinan di rumah dibedakan menjadi dua yaitu persalinan di rumah terencana dan persalinan di rumah yang tidak terencana. Persalinan di rumah dikatakan terencana jika seorang ibu yang bermaksud untuk melahirkan di rumah memenuhi ketentuan medis dan kriteria lingkungan sebagai bagian perinatal yang optimal dan mempunyai penolong persalinan yang qualified yang bekerja di dalam sistem pelayanan kesehatan dimana memberikan akses terhadap peralatan, personel yang spesialis, atau hospitalisasi bila diperlukan. Sedangkan persalinan di rumah yang tidak terencana menggambarkan persalinan yang tidak terawat, dan persalinan yang terjadi tanpa infrastruktur atau dukungan sistem pelayanan kesehatan (Kukulu \& Once, 2009) dalam (Wardayani, 2013). Perhatian medis dan kondisi higiene yang tepat selama persalinan dapat mengurangi risiko infeksi dan memudahkan manajemen komplikasi yag dapat terjadi pada ibu dan bayi baru lahir.

Hasil penelitian didapatkan bahwa sebagian besar informan mengemukakan memilih persalinan di rumah karena bayinya mau keluar atau terlanjur keluar (kebrojolan). Bidan sampai di rumah informan mayoritas bayi sudah keluar, Bidan hanya memotong tali pusatnya atau hanya membantu mengeluarkan placentanya saja. Menurut informan bahwa sudah ada niat untuk melahirkan di fasilitas kesehatan baik itu di rumah Bidan atau di Poned (Puskesmas), juga sudah menyiapkan peralatan yang dibutuhkan pada saat persalinan. Seperti juga disampaikan oleh informan Bidan bahwa mayoritas ibu hamil sudah dalam pembukaan lengkap atau bahkan bayi sudah keluar, sehingga usaha untuk membawa informan ke fasilitas sudah tidak memungkinkan dengan kondisi tersebut, yang akhirnya informan terpaksa harus lahir di rumah. Melihat hal tersebut dapat disimpulkan bahwa informan melahirkan tidak direncanakan sebelumnya. Seorang ibu hamil perlu membuat rencana persalinan bersama anggota keluarga dan Bidan, karena dengan adanya rencana persalinan akan mengurangi kebingungan dan kekacauan pada saat persalinan dan meningkatkan kemungkinan bahwa ibu akan menerima asuhan yang sesuai serta tepat waktu. Menurut (Nolan, 2010) menyatakan bahwa seseorang memilih melahirkan di rumah tentu karena memiliki beberapa alasan. Terkadang karena perasaan mantap terhadap tempat yang akan dipergunakan melahirkan bayinya, yang lain merasa lebih rileks berada di rumah sendiri. 
Berdasarkan penyampaian informan bahwa banyak yang tidak merasakan nyeri saat proses persalinan berlangsung bahkan bingung apakah nyeri yang dirasakan adalah nyeri tanda persalinan atau nyeri karena sakit pinggang saja. Kondisi tersebut dimungkinkan karena ambang nyeri yang dirasakan sedikit oleh informan.. Hal ini diasumsikan berkaitan dengan pekerjaan atau aktifitas keseharian yang dilakukan oleh informan. Informan biasa beraktifitas dengan berjalan jauh baik untuk memenuhi kebutuhan sehariharinya misalnya mencuci, mengambil air untuk kebutuhan sehari yang letaknya tidak terlalu dekat dengan medan yang tidak mendukung. Seperti diungkapkan oleh Balaskas (1992) bahwa Ibu hamil yang aktif beraktifitas saat hamil cenderung lancar saat menjalani proses persalinan. Seperti tampak pada proses persalinan informan ini. Berdasakan hal tersebut kiranya perlu menjadi masukan atau perhatian bagi Bidan dalam memperkiraan waktu saat akan memberikan asuhan persalinan.

Asumsi peneliti dari penyampaian informan dapat disimpulkan bahwa sebenarnya informan lebih menyenangi untuk melahirkan di rumah dengan berbagai alasan yang mereka sampaikan diantaranya merasa lebih nyaman terkait adanya dukungan keluarga, dan lingkungan yang tidak asing lagi serta kepraktisan dengan persiapan alat yang dibutuhkan dalam persalinan. Mereka menyadari kalau melahirkan harus ditolong oleh tenaga kesehatan (Bidan) juga mengetahui akan adanya program pemerintah tentang persalinan harus dilakukan di fasilitas kesehatan, namun untuk mengikuti anjuran tersebut belum dapat mereka lakukan, terlepas dari kondisi fisik informan sehingga dampaknya mereka menghubungi Bidan jika sudah mendekati persalinan dengan harapan bisa bersalin di rumah atau akhirnya bayi lahir sebelum Bidan datang. Persepsi jauh dekatnya fasilitas kesehatan dan tempat tinggal masih beragam, bila dikaitkan dengan medan dan transportasi masih ada yang menyebutkan jauh tetapi ada pula yang menyatakan dekat, bila dikaitkan dengan wilayah Sitopeng ada di Kota Cirebon.

\section{Keuntungan Bersalin di Rumah}

Hasil penelitian didapatkan bahwa banyak keuntungan yang dirasakan oleh informan saat melahirkan di rumah diantaranya merasa nyaman berada di lingkungan keluarga karena ada dukungan dari keluarga, ada yang menemani, merasa tenang karena dapat mengawasi anak yang lain, bisa beraktifitas, tidak merasa 
repot karena harus mengangkut barang bawaan untuk persiapan persalinan. Hal ini sejalan dengan pendapat yang dikemukanan oleh (Wardayani, 2013) bahwa keuntungan yang bisa diperoleh dari persalinan di rumah anatara lain ibu bisa merasa lebih terjamin dan nyaman, suami dan keluarga dapat memberikan bantuan pada setiap tahap proses persalinan. Persalinan di rumah juga memberikan peluang yang besar untuk meningkatkan kenyamanan fisiologis dan psikologis pada periode postpartum dan selama menyusui.

Sementara itu Safrudin dalam (Wardayani, 2013) menyatakan bahwa banyak ibu senang melahirkan di rumah disebabkan oleh beberapa faktor yaitu : adanya dukungan dari keluarga, ibu berada dalam lingkungan yang dikenal, dimana mereka memiliki kendali terhadap tubuhnya, keadaan dilingkungan sendiri menimbulkan rasa tenang dan tentram pada ibu yang akan melahirkan, berdasarkan perbandingan dengan pengalaman melahirkan di rumah sakit, dalam lingkungan yang kurang memiliki sentuhan pribadi, dan penuh dengan peraturan serta staf yang sibuk.

Menurut peneliti dukungan psikologi, bantuan dan lingkungan yang dikenal oleh ibu saat persalinan membuat ibu bebas beraktifitas dan merasa tenang, membuat rileks dan tenang juga tubuhnya termasuk kontraksi otot-otot rahim, sehingga membuat ambang nyeri menjadi sedikit dan mempercepat proses pembukaan dalam persalinan.

\section{Kerugian yang dirasakan Informan saat Bersalin di Fasilitas kesehatan}

Informasi yang disampaikan oleh informan berkenaan dengan perasaan yang dirasakan saat bersalin di fasilitas kesehatan lebih kepada kenyamanan atau kepraktisan serta akses ke fasilitas kesehatan. Hasil penelitian didapatkan bahwa beberapa informan menyatakan merasa kerepotan berkaitan dengan barang-barang yang harus dibawa jika melahirkan di rumah Bidan, apalagi jika ada beberapa barang yang tertinggal di rumah, karena transportasi yang kurang memadai, jalanan yang rusak termasuk harus melewati sungai terlebih dahulu yang tidak bisa dilewati oleh kendaraan. Merasa tidak enak harus pulang pergi jika persalinan ternyata masih membutuhkan waktu yang lama, merasa tidak nyaman karena harus meninggalkan anak yang di rumah, meskipun terkait hal tersebut Bidan sudah berusaha untuk memfasilitasinya.

Menurut peneliti pada dasarnya kondisi tersebut terjadi karena jika informan 
berada di rumah Bidan merasa tidak bebas dalam beraktifitas seperti layaknya berada di rumahnya, mobilisasi terbatas hanya disekitar tempat tidur berbeda jika informan berada di rumah sehingga proses persalinan dirasakan lama oleh informan, belum lagi ditunjang oleh masih adanya pengaruh budaya yang menyatakan bahwa kalau melahirkan bukan di rumah sendiri dpat membawa sial.

\section{Perasaan pada saat Bersalin ditolong oleh Petugas Kesehatan/Paraji}

Berdasarkan hasil penelitian didapatkan bahwa kesadaran informan untuk melahirkan di tenaga kesehatan (Bidan) cukup tinggi, meskipun beberapa diantaranya masih ditemani dukun disamping Bidan. Mereka menyatakan bahwa lebih enak melahirkan di Bidan karena sifat ramahnya, sabar, dikunjungi setelah melahirkan, tidak mengeluarkan biaya persalinan, hanya mengeluarkan biaya untuk pembuatan akte saja sampai dengan kalau di Bidan bisa cepat kembali sehat karena mendapat suntikan ataupun obat oral. Sehingga lebih memilih Bidan dibandingkan dukun/paraji. Selain itu jug Bidan memiliki ilmu sehingga jika ada hal-hal kegawatadaruratan Bidan bisa menanganinya.Kesadaran yang tinggi akan penolong persalinan dengan Bidan dimungkinkan karena upaya yang sudah dilakukan oleh Puskesmas melalui program Kelas Ibu yang sudah dijalankan

\section{Jarak ke Fasilitas Kesehatan}

Hasil penelitian mengungkapkan bahwa sebagian informan tidak mempermasalahkan jarak dari rumah ke fasilitas kesehatan untuk melahirkan di fasilitas kesehatan, karena sudah ada fasilitas berupa sarana transportasi yang disediakan oleh Puskesmas untuk menjemput ibu hamil yang akan melahirkan di fasilitas kesehatan. Beberapa dari informan yang tinggal di salah satu daerah yang memang aksesnya terbatas, merasa jaraknya terlalu jauh dan merasa kerepotan kalau harus menyebrangi sungai dengan berjalan kaki atau ditandu saat dalam proses persalinan untuk sampai menuju kendaraan yang memang tidak bisa sampai ke rumah informan, sehingga didaerah tersebut sebagian besar melahirkan di rumah dengan penolong Bidan.

Tindakan mengantisipasi kondisi demografi yang kurang memadai sudah dilakukan dengan baik oleh Puskesmas dengan menyediakan transportasi gratis bagi ibu yang akan melahirkan di fasilitas kesehatan untuk bisa memberikan 
pelayanan yang terbaik bagi masyarakat, namun kiranya perlu sosialisasi kembali karena masih ditemukan informan yang belum mengetahui informasi tersebut.

\section{Persepsi Bidan tentang Persalinan di Rumah}

Hasil penelitian mengungkapkan bahwa persalinan di ruamh dapat dilakukan asal dengan persiapan yang matang. Meskipun persalinan adalah suatu hal yang fisiologis serta bisa dilaksanakan di rumah tapi bukan berarti semua persalinan bisa dilaksanakan di rumah karena ada hal-hal yang bisa terjadi diluar kendali, meskipun terkadang sudah dilakukan penafisan dengan sebaik-baiknya. Bila terjadi kegawatdaruratan dengan kondisi lingkungan tempat persalinan yang kurang memadai maka bisa berdampak kepada keselamatan ibu dan bayi.

Menurut pendapat peneliti bahwa persalinan di rumah adalah hak ibu yang akan melahirkan, kita sebagai tenaga kesehatan hanya bisa memfasiltasi supaya proses persalinan bisa berjalan dengan aman, ibu dan bayi sehat serta selamat. Upaya yang bisa kita lakukan yaitu melalui deteksi dini (penafisan) apakah kehamilan ibu normal dan memungkinkan bisa melahirkan di rumah atau dengan komplikasi yang harus melahirkan di fasilitas kesehatan. Mengenai adanya kebijakan pemerintah bahwa persalinan harus difasilitas kesehatan dengan tujuan bahwa supaya persalinan berjalan dengan aman sebagai upaya menurunkan angka kematian Ibu dan Bayi. Peneliti berpendapat bahwa Puskesmas sudah melakukan upaya untuk mewujudkan peraturan pemerintah itu dengan baik melalui fasilitasi penjemputan ibu yang akan melahirkan di fasilititas kesehatan, melakukan pemantauan atau kunjungan rumah. Namun alangkah baiknya jika kita tidak memaksakan kehendak, bagaimanapun ibu melahirkan punya otonomi terhadap dirinya, mungkin dengan kerjasama yang baik semua pihak baik, Puskesmas dengan kesiapan SDM dan peralatannya yang memadai, ibu termasuk keluarga dan sarana yang mendukung dapat memujudkan persalinan yang aman, ibu dan bayi sehat serta selamat.

\section{Keuntungan yang dirasakan pada saat menolong Persalinan di Rumah}

Keuntungan yang dirasakan penolong pada saat menolong persalinan di rumah diantaranya yaitu waktu observasi persalinan menjadi lebih singkat karena mayoritas ibu melahirkan memanggil Bidan dalam kondisi pembukaan lengkap atau bayi sudah keluar sehingga tidak 
memungkinkan untuk dibawa ke fasilitas kesehatan, tidak direpotkan dengan persiapan atau perlengkapan ibu bersalin, tidak menyediakan makanan serta tidak mengeluarkan transport jemputan. Namun demikian persalinan di rumah harus dipertimbangkan dulu kesiapannya, banyak juga kerugian yang dirasakan karena meskipun persalinan merupakan suatu hal yang fisiologis akan tetapi tidak menutup kemungkinan dapat terjadi kegawatdaruratan dimana hal ini juga akan mempersulit penolong persalinan terkait kesiapan diri penolong dan kelengkapan alat yang dibawa, dan juga kondisi tempat persalinan yang mana dengan kondisi pasien yang siap untuk melahirkan ataupun bayi sudah diluar, dimana Bidan memiliki sedikit waktu untuk melakukan observasi.

\section{Hambatan Saat Menolong Persalinan \\ di Rumah}

Banyak hambatan dibandingkan dengan manfaat dari menolong persalinan di rumah yang selama ini dialami oleh informan, terutama jika terjadi gewatdaruratan yang tidak pernah di prediksi sebelumnya, seperti yang terjadi bahwa mayoritas Bidan dipanggil dalam kondisi pembukaan lengkap sehingga tidak cukup observasi yang dilakukan, hal ini berdampak juga terhadap kesiapan penolong, kesiapan alat dan obat-obatan yang tersedia. Melihat kondisi tersebut perlu kiranya peningkatan kembali pemberdayaan SDM terkait kerjasama tim, kesiapan alat dan obat-obatan yang memang sangat diperlukan dalam penanganan kondisi kegawatdaruratan.

\section{Alasan Masayarakat tetap memilih Persalinan di Rumah}

Hasil penelitian didapatkan bahwa informan mengetahui bahwa sebagian besar ibu melahirkan di rumah karena merasa nyaman berada di lingkungan keluarganya, ada dukungan penuh dari keluarga, masih bisa beraktifias, nyaman karena bisa mengawasi anak yang lain, tidak asing dengan lingkungan tempat bersalin.

Diketahui kenyamanan baik fisik maupun psikologis sangat mendukung terhadap proses persalinan, dengan demikian hal ini bisa dijadikan sebagai masukan untuk perbaikan di poelayanan baik di rumah Bidan maupun Poned, untuk kiranya bisa menyiapkan tempat persalinan layaknya mendekati lingkungan rumah, dimulai dari hal yang kecil kebebasan adanya pendampingan persalinan, kebebasan beraktifitas (mobilisasi) jika tidak ada indikasi, maupun desain ruangan serta penataan alat-alat sesuai kebutuhan. 


\section{KESIMPULAN}

1. Sebagian besar ibu bersalin menyukai persalinan di rumah dengan alasan kepraktisan dan kenyamanan.

2. Masih terdapat pengaruh budaya terhadap keputusan ibu memilih persalinan di rumah.

Direkomendaikan bagi Puskesmas diharapakn meningkatkan kembali kerjasama lintas sektoral yang sudah terjalin dengan baik, melalui peran aktif kader, tokoh masyarakat dalam berbagai kegiatan khususnya kesehatan ibu dan anak.

\section{UCAPAN TERIMAKASIH}

Ucapan terima kasih kami sampaikan kepada Direktur Poltekkes Kemenkes Tasikmalaya, Ketua Program Studi D.III Kebidanan Cirebon, Kepala Dinas Kesehatan Kota Cirebon, serta Kepala Puskesmas Sitopeng Kota Cirebon.

\section{REFERENSI}

Aprillia, Y. (2013). Indahnya Melabirkan dalam Air. (A. Noverina, Ed.) (Edisi I). Jakarta Gramedia Widiasarana Indonesia.

Basrowi dan Suwandi. (2008). Memahami Penelitian Kualitatif. Jakarta: Rineka Cipta.

Dinkes Kota Cirebon. (2013). Profil
Kesehatan. Cirebon.

Nolan, M. (2010). Kelas Bersalin. (T. Perdanawati, Ed.) (Cetakan I). Yogyakarta: Golden Books.

Notoatmodjo, S. (2005). Promosi Kesehatan Teori dan Aplikasi. Jakarta: Rineka Cipta.

Prasetyawati, E. (2012). Kesehatan Ibu dan Anak (Cetakan I). Yogyakarta: Nuha Medika.

Sugiono. (2012). Memahami Penelitian Kualitatif (Ketujuh). Bandung: Alfabeta.

Wardayani, E. (2013). Analisis Faktor yang Mempengarubi Ibu dalam memilih Persalinan di Rumah oleh Bidan di Wilayah kerja Puskesmas Labuban Ruku Kabupaten Batubara Tabun 2013. Universitas Sumatera Utara. 